\title{
A PROTESTANT VIEW OF POPULATION CONTROL
}

\author{
RrChard M. FagleY*
}

To discuss this subject from a Protestant point of view requires some preliminary clarifications. In the first place, there is no systematic or widely authoritative formulation of the Protestant position. That would be contrary to both the history and genius of Protestantism. A study of statements by the various churches in regard to responsible parenthood offers rather convincing evidence that a real and significant consensus is in the making. There is a rapidly growing body of theological conviction on the ends of marriage and the means of family planning. But this emerging Protestant consensus has the incompleteness of an historical evolution. Neither the presuppositions nor implications have been elaborated in a systematic way.

Consequently, to present this evolving consensus in a coherent manner requires more than a little personal analysis and interpretation. For this task, no authority can be cited other than the possible sense that the analysis may make. While the writer hopes that this presentation is just to the actual consensus in process of becoming, it should be clear that he writes in a personal capacity. The views here expressed in no way commit either the Commission that he serves or its parent bodies, the World Council of Churches and the International Missionary Council. At the time of writing, the so-called Mansfield Report, the findings of the Ecumenical Study Group on Responsible Parenthood and the Population Problem, appears the most representative expression of non-Roman Christian opinion. ${ }^{1}$ Yet, as the World Council Executive Committee noted, in authorizing its publication as a document for study, it had not been adopted by any committee of the World Council of Churches. ${ }^{2}$

Furthermore, while official statements in certain communions have considerable authority for their members, this is not the case in other Protestant churches. Even less can any formulation or application of doctrine be made binding for Protestantism as a whole. The idea is contrary to the ethos of the Reformation and to the nature of the present fellowship of churches. It is only as the insights of ecumenical statements commend themselves to the leaders and members of the churches that they acquire a kind of de facto authority. The distinction made by my Congregational forbears between "ministerial" or spiritual authority and "magisterial" authority may have application here.

- A.B. 1932, B.D. r935, Yale University. Executive Secretary, Commission of the Churches on International Affairs, The World Council of Churches and the International Missionary Council. Secretary, Ecumenical Study Group on Responsible Parenthood and the Population Problem, Mansfield College, Oxford, 1959. Author, The Population Explosion and Christian Responsibilitix (1960).

${ }^{1}$ See $A$ Report on Responsible Parenthood and the Population Problem, 12 Ecunsenicat Rev. 85 (r959) [hereinafter cited as Report], for the text of the Report.

Ilbid. 
Indeed, it can be argued that a fundamental assertion of the Protestant consensus regarding responsible parenthood is that there is no substitute for the responsibility of husband and wife to make their own prayerful and conscientious decisions in this area. It is the couple that is called to the vocation of responsible parenthood, and no court of the churches has comparable jurisdiction. In fact, the central role of husband and wife in regard to the family has been so much in the forefront of Protestant thought that a number of denominations, particularly those with a free church polity, have been very slow to face their own duties to provide relevant principles of guidance. As the writer has argued before, they have used the major responsibility of the couple as an excuse for evading the teaching obligations of church leadership. ${ }^{3}$ Fortunately, this situation is rapidly improving.

The wider acceptance of the church's task to provide spiritual and ethical guidance, however, does not mean any diminution of stress upon familial responsibility. This is particularly true in regard to the family vis-à-vis other secular authorities such as the state. There is developing in Evangelical circles, as we shall see, at least some recognition that the state has legitimate functions to perform in relation to its own and international population problems. But these functions are seen as distinctly subordinate to the primary role and rights of the family. It is to husband and wife that God has given the responsibilities of parenthood, and any effort by the state to arrogate unto itself the authority of husband and wife is an invasion of fundamental and God-given rights.

Thus, the term "population control" needs to be delimited and defined if it is to serve as the subject for a useful analysis from the perspective of Christian doctrine. As it stands, the term rather suggests that the state has a prerogative to determine the size of its population and to exert control through corresponding policies. This is, to be sure, an ethical issue. But there is little to be said about it from a Christian point of view, except to condemn it. This applies equally to coercive measures to reduce population growth, such as forced migration or compulsory separation of the sexes, and to coercive efforts to accelerate population growth through massive propaganda or the arbitrary denial of the means for family planning. The proper role of the state is secondary and subordinate. The rights of control rest with the family.

Consequently, the term "population control" is a little awkward, since it puts the social cart before the horse of family authority and decision. "Fertility regulation" is a more neutral concept and will here be regarded as a synonym for "population control."4 The favored term in Protestant circles is "responsible parenthood," because it puts the focus on the parents, because it reflects a fundamentally affirmative attitude towards parenthood, and because "responsible" indicates the extent to which, with the advancement of knowledge and medical science, parenthood has been raised

${ }^{3}$ Richard M. Faglex, The Population Explosion and Christian Responsibitity 9 ( 1960 ).

"Fertility regulation" is also preferable to "birth control," because of the emotional and negative connotations the latter has acquired; also, "birth control" is a misnomer for "conception control," the concept usually meant. 
to the level of ethical decision. Another merit is that the term stresses motives and ends, rather than means, which are regarded in the Protestant consensus as subordinate issues. Most of this analysis will be concerned with responsible parenthood.

The matter here is presented under four heads. After a brief preliminary consideration of the historical background, the substantive issues are treated under the ends of marriage, the means of family planning, and briefly, the duties of the state.

\section{Historical Background}

The earliest Protestant church statement favorable to the principle of contraception was made some seventy years after the Sacred Penitentiary in Rome in 1853 had given cautious support to the idea of family limitation through periodic continence. ${ }^{5}$ Practically all of the Protestant pronouncements in support of family planning have been made during the past three decades, and the more significant statements have largely been issued during the past few years.

This does not mean, of course, that Protestant families were equally backward in facing up to the necessities of fertility regulation. As health conditions and medical knowledge advanced in the areas of European settlement, so that a larger percentage of children survived, efforts to limit the number of pregnancies undoubtedly grew in millions of good Protestant homes, including those of the married clergy. The growing complexity and costliness of education, which has ever been a major Evangelical concern, was a particularly strong argument for family limitation. Concern for the health of mother and child also argued for the proper spacing of children. While it seems likely that secularized families practiced conception control more widely than those that were church-oriented, the census data in predominantly Protestant countries offer sufficient evidence of the general trend.

The countries of north-west-central Europe had a crude birth rate of from thirty to thirty-two per thousand during the middle of the nineteenth century, but there was a steady decline after the r870's. The rate by the end of World War II was about nineteen per thousand. The same phenomenon is seen in the decline of large families." In Great Britain, for example, ${ }^{7}$

four or more children were born to the great majority ( 63 per cent) of the couples married around 1860 , but to only 20 per cent of those married in 1925 . The most frequent numbers were five, six, and seven in the earlier group, and one or two in the later group.

\footnotetext{
"The first clear statement to this effect, although later called "grudging" permission by an Anglican commission, was probably in 2 resolutions of the Lambeth Conference of the Anglical Commission in 1930-resolutions $x_{3}$ and 15 . The key resolution, the latter, is quoted in M. A. C. Warren ET AL., The Family in Contemporary Society 225 et seq. (1958). Stanislas de Lestapis, S.J., refers to an earlicr statement by the Church of England in 1923. Stanislas de Lestapis, La Limitation des Naissances ['THE Limitation of BiRTHS] 12 (I959).

'U.N. Dep't of Economic and Social Affairs, Determinants and Conseguences of Population Trends $7 x$ et seq. (ST/SOA/Ser. A/I7) (U.N. Pub. Sales No. 1953.XIII.3).

TId. at 73 .
} 
As the authors of a U.N. study conclude: ${ }^{8}$

In recent years, there is almost universal agreement that the major part, if not all, of the decline in family size has been brought about by the practice of family limitation.

In short, it seems rather clear that Protestant practice in the more-developed countries, at least, was considerably ahead of Protestant pronouncement in the acceptance of contraception and related methods of family planning. In this as in other instances that could be cited, many conscientious Evangelical husbands and wives were using the basic freedom of the Christian couple in efforts to make their parenthood responsible without tarrying for tardy church leadership. The "fault," if such it can be called, lay with the latter, in the writer's view, in its failure to examine sufficiently either the Biblical teaching bearing on marriage and the family, or the theological and ethical implications of the new knowledge of procreation and contraception. It is easier to say this, now that the shortcomings are being redressed, but Protestant history in this matter offers grounds for penitence.

The main reasons for the long Protestant neglect of the doctrine of responsible parenthood seem to be nontheological. The Reformation was born in sections of Europe that had been badly depopulated by the Black Death and the Hundred Years War. Given the low state of medical knowledge and the high level of infant mortality, the deterrent to any kind of family planning seems clear. Also, the knowledge of contraception was apparently much lower than in classical times. Consequently, while issues of sex and marriage form an important area of dissent from Rome in the Reformation, neither the doctrine of parenthood nor the implications of the dissent for the family were seriously examined.

In neither Luther nor Calvin is there any doubt about procreation as a major purpose of marriage, although children are regarded somewhat more as the fruit of conjugal relations and the divine gift that blesses the married state than as the essential and primary end. ${ }^{9}$ Luther agreed with Augustine that offspring constituted one of the principal goods of matrimony, although he did not necessarily put it first. He did not quarrel with the thesis that marriage was designed for the increase of the race, but he saw children, in man's fallen state, not so much in relation to a built-in law of nature, as in relation to God's overriding will, which cannot be thwarted by sinful men, and to God's mercy, which despite the sins of lust, blesses the home with progeny and the gladness of motherhood. "Propagation is not in our will and power. . . . Creation is of God alone." Luther saw the family, despite its troubles that reflect man's sinful condition, as a "school for character," where "the Christian virtues find their readiest exemplification."10

\footnotetext{
Id. at 75 .

- The following paragraphs on the Reformation are based upon ch. 13 of the writer's book, FAGLEY, op. cit. supra note 3, at 189 et seq. (1960), by permission of the publishers, the Oxford University Press. ${ }^{10}$ Roland H. Bainton, What Christianity Says About Sex, Love and Marriage 79 (I957). Bainton also quotes a nice excerpt from Luther's Tabletalk \#4786, showing Luther's warm love of family. Id. at 82 et seq.
} 
Calvin, taking more strictly than Luther the Old Testament as valid moral law, was closer to the natural law position of Rome. The injunction to "increase and multiply" was still normative, and except for the very few granted the gift of celibacy, constituted a positive command to marry. One of Calvin's charges against the Roman priesthood was that they were evading their social responsibility, since most were in the ungifted category. The nexus between sex and procreation was important to Calvin as elevating the man-woman relationship in accordance with its original design.

Neither Calvin nor Luther regarded marriage as a sacrament: it is a sign or symbol, a divine ordinance, but not a special occasion of the Holy Spirit instituted by "Christ, as in the case of baptism and communion. Calvin pointed out the inconsistency of Rome in holding marriage a sacrament and yet denying it to the priests and nuns. Both men regarded marriage as fundamentally equal to celibacy in status, and a preferable state except for the gifted few. Both saw it as an essential remedy. for concupiscence in man's state of sin, an argument underscored by the low state of morals in the old Church at the time. Luther was particularly impressed by the need to keep in safe bounds the drives of sex, and on occasion was prepared to countenance bigamy as a lesser evil than fornication or adultery. Calvin's less earthy approach stressed not only strict monogamy, but also proper decorum within marriage. If sexual immoderation is kept within the bounds of marriage, "in the case of believers marriage is a veil, by which the fault is covered over, so that it no longer appears in the sight of God." Thus, for both men, conjugal relations served an important negative function, as it had for Paul, in providing a remedy for concupiscence. ${ }^{11}$ The question of any control of conception in this connection apparently did not arise, since concern about family limitation was not on the horizon. ${ }^{12}$

-. : William Cole seems to be correct in saying that "procreation" remained for them, as for Augustine and Aquinas, the only really positive purpose of sex."13 For Calvin particularly, however, marriage itself served another purpose, which he regarded as in one sense more fundamental-namely, the purpose of companionship. This companionship is primarily social and spiritual rather than sexual, a sharing of mind and interest and experience. As Cole summarizes the view expressed in Calvin's Commentary on Genesis: ${ }^{14}$

'To him, the decisive words in the creation narrative were those of God's, "it is not good that the man should be alone." His design in creating the woman was "that there should be human beings on the earth who might cultivate mutual society between themselves.

${ }^{11}$ Cf. I Corinthians 7 .

${ }^{29}$ Calvin stressed the malignancy of Onan in refusing his brother the title of father. He also said, "Since each man is born for the preservation of the whole race, if anyone dies without children, there "sceins to be here some some defect of nature." 2 John Calvin, Commentary on Genesis 28I (John King transl. 1850 ):

$\therefore:$ : Whliam G. Cole, Sex in Christianity and Psychonnalysis 131 (I955).

* Ii Id. at IIg. 
This concept of marital community, Cole points out, elevated the status of woman as a person, as part of a living organism, in a more just way than was true of Calvin's predecessors. ${ }^{15}$ He described his dead wife as "the best companion of my life ... the faithful helper of my ministry."

While the sexual dimension of marriage is somewhat obscured in this version of the "one flesh" idea, other elements are there and help to keep the idea itself alive in the Puritan tradition. John Milton, for example, in his tract on divorce-which was not untinged with self-interest-appealed to Genesis $2: 18$ as the first command of God. "In God's intention a meet and happy conversation is the chiefest and noblest end of marriage. . . . The chief society thereof is in the soul rather than in the body."16 In such thoughts, part of the old contemplative ideal seems to have been transferred to the nonsexual side of marriage, while the sexual side remained in the shadows-perhaps because it was regarded as having shameful connotations or because it was thought of so largely in terms of the duty of procreation. The idea of "one flesh" was preserved, but not given the fullness of its Biblical meaning. It would reappear in more significant form in the twentieth century.

There were a number of growing points in the Reformers' thoughts on marriage and family life that might have led to new insights on parenthood if their implications had been thoroughly examined. Marriage was freed from subordination to celibacy and given a new dignity. It was less tied to the chariot wheel of procreation, or at least the chains were longer. And even in regard to the marital act, children were regarded somewhat more as a divine blessing upon it than as its primary end and justification. Yet, the implications for parenthood were not examined in any thorough way for nearly four centuries. ${ }^{17}$ Even Anabaptists like Thomas Münzer, and pietists like Count Zinzendorf, who took a more ascetic view of conjugal relations than those in the main stream of development, did not question the nexus between "conjugation" and propagation. For all practical purposes, the ethos of Wittenberg and Geneva and Canterbury was as strongly profertility as that of Rome.

In fact, it could be argued that the Reformers, in challenging the religious primacy of celibacy, which provided as a by-product a limitation of marriage and hence of procreation, fostered a stronger profertility position than that of Rome. There was in the old Church an ambivalence of attitude towards parenthood, going back to early Christian times. In view of the high place given celibacy as a religious vocation, procreation was regarded not as a duty of man as such, but rather of man in marriage. The Protestant depreciation of celibacy, as an exceptional rather than normal vocation, elevated marriage and parenthood as the norm.

Likewise, the Reformation emphasis on the Bible as the sure and sufficient guide to faith brought more into the forefront the profertility ethos of the Old Testament

${ }^{15} I d$. at 120 .

${ }^{10}$ Quoted in Bainton, op. cit. supra note Io, at 10o. Bainton says the Puritan ideal for the manwoman relationship was summed up in the phrase, "a tender respectiveness." Id. at 96.

${ }^{17}$ There were some individual efforts, like that of Schleiermacher, but they had little impact on the Protestant ethos. Cf. Franz Vorländer, Schleiermacher, StTtenlehre [Schleiermacher, The TÉachINGS OF MORAs] ( $185 \mathrm{I}$ ). 
-for the New Testament has little to say on the natural continuation of life, being primarily concerned with its supernatural transformation. This Old 'Testament stress on fruitfulness is best known by the "increase and multiply" verses of Genesis, ${ }^{18}$ which were repeatedly cited in patristic writings against the Gnostic condemnation of procreation as the imprisonment of souls in evil bodies. But the profertility elements in the Old Testament are manifold: the concern for the abundant society, the acceptance of polygamy, the concern for the preservation of the family name or "social immortality," and the institution of levirate marriage as a means to this end." These, even though not taken literally, helped to give the Reformation ethos a strong bias in favor of high fertility.

The profertility elements in the early church, such as the Greco-Roman concept of marriage as a utilitarian contract for the procreation of legitimate issue, the defense against absurd charges of sexual orgies by assertions that marital relations were limited to procreation, and the ancient belief that the male contribution to conception was seed in the full sense and hence its nonprocreative use was a crime-these probably had an impact on early Protestant thought, chiefly through their impact on Augustine. This giant of North African Christianity, who cast such a shadow on both Roman Catholic and Protestant thought, bears a major responsibility for the stress on fertility in both the Scholastic and Reformation formulations. His conversion took the form of a revolt against sexual indulgence, and in this revolt, he condemned any nonprocreative use of sex, including periodic continence. Augustine, in this as in other fields, had a major impact on Luther, as he had had on Aquinas.

The result of all this was a strong bias in Reformation thought in favor of procreation as a prime end of marriage and of the large family as a fulfilment of the injunctions in Genesis. In the underpopulated regions of northwestern Europe, there was no goad to rethink this inherited teaching. Moreover, this area was the staging ground for the Industrial Revolution. There was a new demand for manpower in the making. And as the medical sector of the Industrial Revolution gradually reduced death rates, opportunities for migration to the Americas and other less-developed regions provided safety valves. Technical improvements in contraception also helped to reduce the increase in population. On the other hand, the prudery of the Victorian era created inhibitions to a frank examination of the parenthood question. To raise the question seemed to exhibit a want of confidence in God's providence.

Consequently, it was not until church leaders were prodded by the massive goad of world depression that a new look was taken at the doctrine of parenthood. One is emboldened to make this assertion by reason of the fact that the statements of the 'thirties on behalf of family limitation dealt more with the ethical conclusions than with the theological presuppositions of responsible parenthood. In the more recent

\footnotetext{
${ }^{28}$ Genesis $1: 28,8: 17,9: 7$.

${ }^{10}$ Cf. Faglex, op. cit. supra note 3, at 109 et seq.; for a fuller treatment, see David R. MACz, Hednew MarRiage (1953).
} 
statements, the nontheological factors, as the growing awareness of the population explosion in the underdeveloped world, have continued to play a part. But along with this, there has been a more serious study by Protestant theologians of the meaningof sexuality and of the man-woman relationship. This has given the emerging. Protestant consensus deeper dimensions.

With this brief excursus on the historical background, we turn to a more specific description of the Protestant consensus in the making, starting with the fundamental issue of the ends of marriage.

II

\section{The Ends of Marriage}

An examination of the emerging Protestant consensus on responsible parenthood. must start with the ends or purposes of marriage, since one of the tenets of this consensus is that motives rather than methods form the primary consideration. Despite this fact, there has been little systematic analysis of the meaning of marriage within. God's creation. Most attention has been paid to what the writer would call the. proximate ends of marriage, and specifically to marital companionship, as justified. independently of procreation. The more fundamental assertions are to be inferred. rather than explicitly cited from Evangelical pronouncements.

Nevertheless, the writer would affirm that the basic Protestant assertion regarding: genuine marriage is that it is a spiritual reality, involving a gift of God, the gift. of union or henosis. This union is expressed in physical union, but transcends it. As a commission of the Church of Scotland has stated, "in a real sense every Christian marriage is a new creation, in which body and mind increasingly cooperate in a. spiritual service. . . . It has a physical basis, but its full development embraces all the higher powers of our nature."20 While there is naturally a tendency to identify the gift of henosis with Christian marriage, the more thoughtful statements recognize that marriage is of the order of creation. Thus, the United Lutheran Church stated in 1956 that "marriage is that order of creation given by God in love which binds. one man and one woman in a life-long union of the most intimate fellowship of body and life."21

The fellowship of man and woman in marriage, according to the Baptist Union. of Denmark, goes back "to the creative act of God."22 This is the fundamental affirmation that the mystery whereby husband and wife are enabled to become oneperson or "one flesh" involves a gift of God. As Jesus indicated, God himself is.

${ }^{20}$ Church of Scotrand, God's Will for Church and Nation i21 (I946). Most of the statements cited below, which are in the writer's possession, are not to be found in readily available publications, but. can be secured from the headquarters of the respective denominations. They are available to the special student at the writer's office: 297 Park Avenue South, New York ro, N.Y.

${ }^{2}$ Bonfd of Social Missions, United Lutheran Church of America, Christian Guddance on: Marriage and Famiry Life 3 (n.d.).

22 Text from the Baptist Union of Denmark.

${ }^{23}$ Genesis 2:24; Mark 10:8; Ephesian's 5:31. 
the author of this union-expressed in the term "what God has joined together."24 As the Mansfield Report said in describing elements of the emerging consensus: "The 'two become one' is part of God's grace, to be accepted as a mystery and lived in faith."25

From this concept of marriage as a union created by God is derived the essential idea that the primary purpose of marriage is to cherish and nourish this gift, this "two in one flesh" union or henosis. Part of this stems from the sense of the divinely ordained character of $\operatorname{sex}^{26}$ But it also stems from the awareness that "holy matrimony" is "an honorable estate, instituted of God."27 Consequently, "marriage is a vocation to holiness, through which men and women may share in the love and creative purpose of God," as the I958 Lambeth Conference put it. ${ }^{28}$ "Marriage, in the Christian understanding of it, is a divinely given vocation . . . ," according to the Council for Christian Social Action of the United Church of Christ (U.S.)..$^{29}$

In this underlying assertion about the spiritual and God-given character of genuine marriage, and the obligation to honor the gift by a spiritual response, Evangelicals are close to doctrines affirmed by the other main branches of Christianity, Eastern Orthodoxy, and Roman Catholicism. In the Orthodox view, sanctification, based on the great mysterion in Ephesians, ${ }^{30}$ is the primary end of marriage. As the late Archbishop Michael stated, "The purpose of matrimony is perfection of the married couple . . a cooperation with Divine omnipotence." ${ }^{\prime 3}$ Basically the same point of view was expressed by Pius XI in an important passage of his encyclical, Casti connubii, in $1930:^{32}$

This mutual inward molding of husband and wife, this determined effort to perfect each other, can in a very real sense, as the Roman Catechism teaches, be said to be the chief reason and purpose of matrimony, provided matrimony be looked at not in the restricted sense as instituted for the proper conception and education of the child, but more widely as the blending of life as a whole and the mutual interchange and sharing thereof.

Here, it seems to the writer, there is a potentially important meeting ground of the three main branches of Christian faith, in the common recognition that there is an act of God in the true union of husband and wife, which makes of the two a single personality or "flesh" in the Biblical terminology. This mystery, which was used by Paul to illumine the union of Christ and His Church, also illumines the marriage relationship. Man and wife are called to a high destiny, a divine vocation,

${ }^{24}$ Mark ro:g.

${ }^{25}$ Report 88.

${ }^{20}$ Genesis $1: 27$; Mark ro:6.

${ }^{27}$ The Form of Solemnization of Matrimony, in The Book of Common Prarer.

${ }^{28}$ The Lambeth Conperence r958, Resolution 113 , at 1.56 (x958).

${ }^{20}$ Responsible Parenthood and the Population Problem, A Statement Adopted by the Cosncil of Christian Social Action of the United Church of Christ, Jantuary 30, 1960, Social Action, April 1960, p. 24 .

${ }^{30}$ Ephesians 5:22 et seq.

${ }^{31}$ Greek Archdiocese of North and South America, Greek Orthodox Yearbook 100 (1956).

${ }^{39}$ PiUs XI, ON Christian Marruage 8 (I94I). 
whereby they help to complete the other and fulfill a divine calling. There are many loose ends in this area of potential general Christian agreement, but it is encouraging that such an area can be discerned.

The concept of true marriage as a "new creation," a divine act or gift, has important implications for Protestant doctrine that seem to have been more felt than clearly analyzed or stated. One is that marriage so conceived is obviously a good in itself, and not merely a means to some other end. Another is that marriage as a spiritual reality is under the law of the spirit, and transcends without wholly escaping the law of nature-i.e., the law of biological necessity that governs lesser creatures. In regard to the latter law, man and wife enjoy a God-given freedom to serve and worship God according to the dictates of the spirit. It may be a partial awareness of this that has led to a certain caution in Protestant church statements in regard to marital guidance, lest they infringe the authority of the couple in conscience.

Freedom, however, is always linked with responsibility in the Christian view. And when the ecumenical study group that issued the Mansfield Report attempted to express its understanding of marriage in theological terms, they turned to the Biblical concept of covenant-the covenant of husband and wife in the presence of God, which transcends a human contract. This covenant idea expresses marital responsibility, the commitment of mind and will to a dedicated life together, the voluntary and joyful acceptance of the obligations that flow from the gift of God. As the Mansfield Report stated: $:^{33}$

Marriage as a divine institution can be described in Biblical terms as a covenanted relationship within which man and woman receive the grace, security and joy promised by God to those who are faithful to it. Marriage is the "great mystery" which yet illumines for men the covenant or marriage of Yahweh with Israel (Hosea 2:rgf.), and of Christ with his Bride, the Church (Ephesians 5:23-33, Revelation 21:9; 22:17)....

Thus the covenanted relationship of husband and wife within marriage, is, in the purpose of God, one of total commitment, a total giving of self and a total acceptance of the other, resulting in a union, spiritual and physical, described in the Bible as becoming "one flesh"....

While the above seem to be the half-articulated understanding in the Protestant consensus of the fundamental reality of marriage and of its primary purpose, much more attention has been given to the more familiar ends of marriage-parenthood and companionship. If care for the gift of God is seen as the primary end of marriage, then the better-known purposes become proximate ends, by means of which the principal purpose is served. A third proximate end, the vocation of the couple or of the family, begins to make its presence felt, is hovering in the wings, so to speak, and also merits consideration.

As indicated in the brief historical review, Protestantism has never challenged the importance of parenthood for the married state, the miracle through which man and wife are privileged to participate in God's creative work. Indeed, with the reaction against celibacy as a religious vocation, or its relegation as an exceptional

${ }^{33}$ Report 88 et seq. 
call, there was a more whole-souled and undivided concern for parenthood in Evangelical churches than in the other branches of Christendom. Parenthood is seen as a divinely ordained purpose of marriage, for the completion or embodiment of the "one flesh" union, for the building of the home as a true community of persons, and for the peopling of the earth. ${ }^{34}$ As a participation in the creativity of God, parenthood calls for awe, gratitude, and a sense of responsibility.

The Augustana Evangelical Lutheran Church stated, as the first proposition of its statement on responsible parenthood: "Scripture teaches that children are a gracious gift from God (Gen. 33:5), 'an heritage of the Lord' (Ps. 127:3)...."35 A commission of the Church of Scotland said of children that "their begetting and their birth, the inheritance they bring with them, and the destiny to which they move, all are embraced in the mystery of the divine Providence and of the divine purpose and will."36 The commission added it is only with children that "the family becomes a model in miniature of the great societies. . ."37 The Mansfield group likewise asserted that parenthood is necessary for the "fullness" of marriage. ${ }^{38}$ A report to the Presbyterian Church in Ireland argued that for couples to "refuse to have children, except for some very sufficient reasons, is a sin against God."30

It is unnecessary, however, to multiply citations on this point. The important consideration is that Protestants today stress a far broader concept of parenthood than did their forbears. (A comparable development is the growth of "procreation" into "procreation and education" in the Roman Catholic definition of the primary purpose of marriage.) The encyclical letter of the 1958 Lambeth Conference spoke of "a primary obligation of Christian marriage ... that children may be born within the supporting framework of parental love and family concern, with a right to an opportunity for a full and spiritually wholesome life." ${ }^{* 0}$ Indeed, the Anglican Communion makes "giving responsible security to the child" a third aim of marriage." The Mansfield Conference stressed as a principle to guide parents, "the claims of children as persons in their own rights ... as persons with a right to parental care in infancy and youth and to a proper equipment from society to serve God fully in it themselves." 42

The strong and traditional Protestant concern for education has played an important role in fashioning support for the doctrine of responsible parenthood, that "family planning, in such ways as are mutually acceptable to husband and wife in Christian conscience ... is a right and important factor in Christian family life."

${ }^{34}$ Genesis $r: 28$.

ss Compendium prepared by Dr. Norman Goodall and the writer for the Mansfield Conference, April 1959, pt. I, at I (unpublished) [hereinafter cited as Compendium].

so Church op Scotland, op. cit. supra note 20, at 138 .

${ }^{27} \mathrm{Id}$. at I22.

${ }^{38}$ Report 89.

s" See Compendium pt. 2, at 4 .

10 The Lambeth Conference 1958, at 1.22 (1958).

1 Id. at $2 . x 43$.

12 Report 90.

18 The LaMbeth Conference 1958, Resolution I15, at I.57 (1958). 
The increasing complexity and costliness of an adequate education in an interdependent and technologically complex civilization have made their impact on Protestant ideals of the optimum family size. It has been increasingly recognized that to maintain or improve the quality of education, there must be a limitation on the quantity of procreation. Commitee $\mathrm{V}$ of the $195^{8}$ Lambeth Conference called to task couples "who carelessly and improvidently bring children into the world trusting in an unknown future or a generous society to care for them."44

In addition to stress upon the right of children to love and care, to nurture and training, the emerging Evangelical doctrine of responsible parenthood has emphasized the spacing of children for maternal health. As for exercising the power of procreation, said the United Lutheran Church, "the health and welfare of the mother-wife should be a major concern in such decisions." 45 The importance of the mother in the family, in fact, has led to rather general Protestant support for therapeutic abortion when necessary to save the health or life of the mother. There has been about as much support for the spacing of children as for the limitation of the family. This seems to be particularly true of Christian opinion in Asia and Africa, to judge from available evidence.

Both ideas assume that parents have means to control, within reasonable limits, the power of reproduction. In this respect, the new knowledge of ovulation and of methods to prevent conception plays an important part in the concept of responsible parenthood. One of the key sentences in the Mansfield Report was this: ${ }^{46}$

A knowledge of the relation of sexual love to the procreative process gives to a couple the power, and therefore the responsibility, to lift the begetting of children out of the realm of biological accident, or "fate," into the realm of personal decision-which is also the realm of grace, where man is free to wait upon God and consciously to respond to His will.

Knowledge is here seen as a "liberating gift of God," imposing corresponding duties for its responsible use. The implication is that the medical knowledge that enables a couple to avert conception is no more "artificial" or "unnatural" than the medical knowledge vouchsafed for the reduction of disease and premature death.

The Protestant consensus is in basic agreement with the 195 I statement of Pius XII that "serious reasons, such as those found in the medical, eugenic, economic and social indications, can exempt for a long time, perhaps even for the whole duration of the marriage, from this positive duty" ${ }^{\prime 47}$ to procreate, imposed on couples using their marriage rights-although the writer does not recall any specific Protestant sanction for a voluntarily childless marriage. Recent statements have given more attention to the social "indications," in view of the dilemmas of the population explosion. The Mansfield Report stated that ${ }^{48}$

"Id. at 2.146 .

4B Bonrd of Social Missions, op. cit. supra note 2I, at 3.

10 Report 89.

${ }^{47}$ Address to Italian Catholic Union of Midwives, 43 Acta Apostolicae Sedis 835,846 para. 36 (195I) (in Italian).

${ }^{4}$ Report 90. 
responsible parenthood has to take account of . . . factors of special urgency in regions where a rapid multiplication of population co-exists with poverty, insufficient supplies of food and other necessities of life, and a low potential for rapid economic development.

The main assertion in current Protestant statements that differs from Roman Catholic teaching on the ends of marriage is the assertion that mutual love and companionship form a coordinate rather than subordinate purpose in relation to parenthood. This applies to the Anglican Communion as much as to those churches which are less close to the Thomistic tradition. As Committee V of the $195^{8}$ Lambeth Conference said, sexual companionship and procreation are "not subordinated one to the other; they are not directly related to one another...."40 The Committee pointed out that Christ's teaching about the ends of marriage dealt directly only with the companionship purpose, the personal relationships between husband and wife. This is also true of the letters of Paul, at least the major epistles acknowledged by modern scholars to have been dictated by him. This does not mean, of course, a New Testament antipathy towards parenthood. ${ }^{50}$ But it strongly suggests an independent status for the nonprocreative purposes.

In the Presbyterian tradition, the Westminster Confession, following the insight of Calvin on the importance of Genesis 2:18, gave "the mutual help of husband and wife" as the first object for which marriage was ordained, listing "the increase of mankind" as the second. ${ }^{.1}$ (The Roman Catechism of 1572 , incidentally, followed the same order in regard to the reasons for marriage, the fines operantis.) Contemporary Protestant statements do not make parenthood subordinate to marital companionship, but assert their essentially equal and separate status.

Sherwin Bailey, able Anglican scholar in this field, ${ }^{62}$ emphasizes the contribution of the relational philosophy of Martin Buber in the new theological understanding of the importance of the man-woman relationship. But there were undoubtedly a number of influences that brought a greater focus of attention on the significance of marital companionship. The major Protestant theologians of our time, as Barth, Brunner, Niebuhr, and Tillich, agree on the validity of the marital union apart from the purpose of procreation. Practically all of the recent Protestant church statements have made this point. Most couples require regular coitus for the nourishment of love and companionship, through which the "one flesh" union is perfected. This God-ordained aim of marriage gives full sanction for the marital act even when parenthood is not sought. It is also expressed in the broader aspects of mutual help and sharing of life.

Dr. Bailey, in fact, has argued that the relational purposes of coitus are important for fulfilment of the duties of parenthood by contributing to the proper environment of the family. He writes: "It cannot too strongly be stressed that the well-being

40 The Lambeth Conference 1958, at 2.143 (1958).

${ }^{\text {to }}$ Cf. FrGLEY, op. cit. supra note 3 , at 125 et seq.

51 Westaninster Confession ch. 24 (1647).

sa Cf. Sherwin Bailey, The Mystery of Love and Marriage (i953); Sexuat Relation in Christian ThovgerT (I959). 
of the family depends to a greater extent than has perhaps been recognized hitherto, on the well-being of the one flesh."153 This argument, of course, goes beyond the Protestant consensus, but underscores the significance placed on the relational value of the marital act. The 1958 Lambeth Conference spoke of the "sacramental expression in physical union." ${ }^{54}$ At the same time, there are frequent warnings in Protestant statements against allowing marital companionship to lapse into sensuality and selfishness. Marital freedom also means marital responsibility.

A third proximate end of marriage seems to be in the making in Protestant thought, although there is not very much tangible evidence for the assertion. This is the idea that the concept of Christian vocation can be applied to the couple as well as to the individual. If the concept of marriage as a "new creation," the mystery of the "two become one," is taken seriously, then the question of the marital vocation becomes significant. To be sure, this vocation is normally expressed in the family. But it is by no means necessarily limited to that mode of expression. Given the emerging higher status of woman, the service of the couple in society apart from the family more frequently has elements of mutuality and joint decision than used to be the case.

One of the repeated warnings in the New Testament is against regarding the family as an ultimate value. The claims of the Kingdom come first. ${ }^{55}$ Such teachings have traditionally been applied to the vocational duties of individuals. But there is no inherent reason why they should not also be applicable to married couples. And, in fact, the Western Church left room for such an application in the "vows-of-chastity" marriage. But if the marital act is not limited to procreation, there is no clear reason to restrict the special religious vocation to the ascetic marriage. The couple enjoying sexual companionship may also be called to a particular mission in society.

Normally, of course, this would not rule out parenthood as part, or major part, of the vocation. But it seems clear that the vocation of the couple may justify family limitation; and it is possible to conceive of special missions in disturbed or dangerous sectors of society, where the voluntarily childless marriage could be justified as a price to be paid for the calling. This possibility was discussed at the Mansfield consultation, although it was not talked through enough to be reflected in the Report. Yet, this concern for vocation is one of the growing edges of the Protestant consensus. Certainly, the vocation of the couple is one of the values that enters into the calculations of responsible parenthood.

\section{III}

\section{- Menns of Family Planning}

From what has already been said, it should be clear that the mainstream of Evangelical thought puts more emphasis on the motives of family limitation than

${ }^{83}$ Quoted in Warren, op. cit. supra note 5 , at 226.

“ The Lanseth Conference 1958, at 1.22 (I958).

"Matthew 10:37, 19:29; Mark 3:35; Luke I1:27-28. 
upon the methods. If, the motives are wrong, no method will make them right. On the other hand, if the motives are responsible, there is considerable latitude as to means. A characteristic of the Protestant consensus is to avoid an a priori hierarchy of values in regard to. means. This is not wholly the case, since there is a clear condemnation of certain methods for contraceptive purposes.

Family limitation through the postponement of marriage, the "moral restraint" advocated by the Anglican priest, Thomas Malthus, ${ }^{50}$ has not, so far as the writer knows, been considered in contemporary Protestant statements. There are a few warnings against marriage by immature young people, ill-prepared for the responsibilities of marriage. But there are also admonitions on the values of parenthood in the early years of marriage. The Augustana Evangelical Lutheran Church statement, for example, speaks of the "rich joys from children born in one's youth (Ps. I:27:4-5)." "j7 It seems clear that other methods for the limitation of families are preferred by Protestant churchmen to the delayed marriage, which restricts the birth r̦ațe of Irreland, for example. , :

Complete marital abstinence, the only method of family limitation sanctioned in Eastern Orthodox statements, also has been given little consideration in contemporary Protestant statements, although the r930 Lambeth Conference regarded it as the "primary and obvious method." ${ }^{\text {p }}$ Karl Barth, in his treatment of the subject, regarded complete abstinence as possibly calamitous, ${ }^{59}$ while Emil Brunner thought it permissible, ${ }^{60}$ despite the Biblical counsel against it. ${ }^{01}$ Most recent Protestant statements, it. seems, regard it as unrealistic, in view of the alternatives. Committee $\mathrm{V}$ of. the $195^{8}$ Lambeth Conference, however, spoke of the "beauty and strength of abstinence mutually accepted." 22

...: Both periodic contipence or the "rhythm" method, sanctioned for right motives in modern Roman Catholic teaching, and the various methods of contraception find general approbation as methods in the emerging Protestant consensus. It is really this group, possibly including coitus interruptus in some cases, that is intended when bodies like the Netherlands Reformed Church (Hervormde Kerk) speak of methods being "in the field of freedom, because circumstances have here their say. . . ."03 Part of the hesitance to distinguish methods within this group may stem from a reluctance on the part of churchmen to infringe on the prerogatives of the medical so Thomas R. Malthus an Essay on the Principle of Population bk. 4, ch. I (2d ed. i803).

ir Compendium pt. I, at I. Committee $\dot{V}$ of the 1958 Lambeth Conference stated: "In general, the ehrlier in a marriage children "are bórn, the better-both for them and their parents. And there is every reason to suggest to young men and women that it is far wiser to postpone marriage for a time than to enter it in constant fear of accidental pregnancy." The LAMBETh Conference 1958, at 2.146 (x958).

${ }^{68}$ See WARREN, Op. cit. supra note 5 , at 225.

3 Karl Barth, Die Kirchliche Dogmatik [ChuRch Dogmatics] 300-II (1932).

${ }^{00}$ Emml Brunner, The Divine. Imperative 368.et seq. (I957): :*

${ }^{62}$ I Corinthian's 7:5. Bonhoeffer argues that "total abstention . . . undermines the physical basis of -marriage and threatens marriage itself "with' nullification and déstruction by robbing it of its fundamental right. It certainly :eliminates the unnatural act of preventing conception, but this is replaced by the unnatural state of a marriage without bodily union." DIETRICH BONHOEFPER, ETHICs 133 (1955).

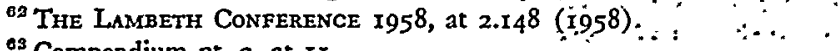

${ }^{-3}$ Compendium pt. 2, at II. 
profession; but part stems from an awareness that the sexual needs and tastes of couples vary considerably, including their differing needs for effectiveness in the prevention of conception, so that it is unwise to make too many refinements.

Thus, the London Yearly Meeting of the Society of Friends states that "this is an intensely personal question and no couple can judge for another," although it warned against coitus interruptus on the grounds that it is "unreliable and may lead to serious nervous trouble." Committee V of the 1958 Lambeth Conference also warning against "any means which interrupts or prevents the fulfilment of coitus," stated that "the means of family planning are in large measure matters of clinical and aesthetic choice, subject to the requirement that they be admissible to the Christian conscience." ${ }^{365}$ This apparently meant the conscience of the particular Christian couple: the Committee went on to say that "Christians have every right to use the gifts of science for proper ends," while the encyclical letter of the 1958 Lambeth Conference stressed acceptability to husband and wife. ${ }^{66}$

The United Lutheran Church stressed that "choice as to means of conception control should be made upon professional medical advice."0t The Church of Finland and the Netherlands Reformed Church took a similar position, the latter adding "that it is not the means, but the motives that are determinant." 68 Likewise, the Augustana Lutheran statement: "It is the spirit in which the means is used, rather than whether it is 'natural' or 'artificial' which defines its 'rightness' or 'wrongness." "To The Mansfield Conference, subsequently supported by the Evangelical and Reformed General Council, found no inherent ${ }^{70}$

moral distinction between the means now known and practiced, by the use whether of estimated periods of infertility, or of artificial barriers to the meeting of sperm and ovumor, indeed, of drugs which would, if made effective and safe, inhibit or control ovulation in a calculable way.

Implicit, at least, in these affirmations is the rejection of the Thomistic thesis that the essential purpose or "nature" of the marital act is procreation. Whatever the biological necessities that bind sex and procreation among the lower species, it is clear that man is not bound in the same way. or to the same extent. Further, marriage serves more than one end, and "sexual union ... [is] the ordained servant of both" companionship and parenthood. ${ }^{71}$ The decision to use the marital act for one or both purposes is a free ethical decision. The use of scientific means to prevent the union of sperm and ovum no more "counterfeits" the marital act than the contraceptive intent "counterfeits" the act when the infertile period is used. This is the thrast of the Protestant consensus.

ot Id. pt. 2, at 7 .

Os The LaMbeth Conference 1958, at 2.148, 2.147 (1958).

${ }^{\circ 0}$ Id. at $2.147, \mathrm{r} .22$.

${ }^{07}$ Bonrd of Social Missions, op. cit. supra note 2I, at 3.

os Compendium pt. ?, at Ir.

${ }^{60} \mathrm{ld}$. pt. $\mathrm{r}$, at $\mathrm{x}$.

io Report $9 \mathrm{r}$.

${ }^{72}$ Id. at 89. 
In regard to voluntary sterilization as a means of fertility regulation, the Protestant consensus is rather inchoate. The traditional objection to bodily mutilation, except for the good of the whole body, while cited in the Report of the $195^{8}$ Lambeth Conference, apparently does not loom very large in Protestant thinking. ${ }^{72}$ The main objections seem to hinge upon the presently irreversible character of sterilization. The permanent operation eliminates the day-to-day process of decision-making, in accordance with changing circumstances, that most Evangelicals have in mind by the term "responsible parenthood." As noted above, the Mansfield Conference found no moral objection, qua method, to the temporary sterilization of an ovulationinhibiting drug, if effective and free from serious side-effects. Consequently, if surgical sterilization can be made fully reversible, many of the misgivings among Protestant leaders would be laid to rest. Even under present circumstances, the $195^{8}$ Lambeth Conference abstained from an outright condemnation, recalling the present lack of effective alternatives in some regions of the underdeveloped world. ${ }^{73}$ The most common Protestant comment is that the question of sterilization needs more study.

The universal Protestant condemnation of abortion as a means of family planning, or for other purposes save to rescue the health or life of the mother, suggests that the dividing line between the ethical and unethical (in terms of method) is regarded as lying at the point where new life begins. The Mansfield Report, for example, considering the permissive, stated: "'Life', however, does not begin until the sperm has fertilized the ovum and conception has taken place."74 Studies of legislation, moreover, indicate that in general, countries of Protestant predominance have rather more stringent laws against induced abortion than countries of other cultures. ${ }^{75}$

The writer does not know of any Protestant discussion as to the status of the fertilized ovum before it becomes implanted in the uterus. This issue may become important if a potential new "oral contraceptive," MER-25, proves effective as a means to destroy in human beings fertilized ova before implantation. Such a drug, if established as effective, safe, and inexpensive, could become technically significant,

\footnotetext{
7a Three demographers with divergent religious backgrounds raise the question whether sterilization, where the need for family limitation was desperate, could not be regarded as for the good of the social organism of the family. In view of the "one flesh" concept of Christian doctrine, it seems a pertinent question. Lorimer, Bourgeois-Pichat \& Kirk, An Inquiry Concerning Some Ethical Principles Relating to Human Reproduction, 4 Socusl Coxpass (1957).

${ }^{78}$ Committee $V$ stated on the negative side the following: "The Committee thinks it right, however, to state that sterilization, now generally an irreversible process, limits the ability of the man or woman to meet changed circumstances (as in depriving a future spouse of the possibility of parenthood), and as such is a major and irrevocable abdication of an important area of responsible freedom. It has psychological and physiological consequences that are as yet unknown and unmeasured, and represents as well a violation of the human body, a body which is God's gift and trust, and only in a limited sense ours to do with as we wish. All agreed with these considerations, although some members felt that in the present state of our knowledge, we ought not to attempt to judge finally for the future." THE LasonthI CONFERENCE 1958, at 2.149 (1958).

${ }^{34}$-Report 91.

${ }^{76}$ Cf. U.N. Secretariat Survey of Legislation on Marriage, Divorce, and Related Torics Relevaxt to Population (ST/SOA/29) (1956), released in March 1956 but valid for 1951; Hope T. Eldridge, Population Policies: A Sunvey of Recent Developments 99-115 (1954).
} 
particularly for less-developed countries. While it would be rash to predict Protestant reactions in such a contingency, the presumption is that the reaction would be generally negative, on much the same ground as that put forward on Roman Catholic presuppositions by Gibbons and Burch: "There is involved an attack upon life already in process of growth, which if not actually human, is intrinsically destined to become such.".76

The foregoing represents the broad picture of the emerging Protestant consensus on responsible parenthood, in so far as the writer understands it, together with a few of the implications that seem to be involved in it. It is far from complete either in the elucidation of doctrine or in the extent of explicit church support. Many churches have not yet spoken on the subject:- There is, however, an acceleration of church pronouncements bearing on Christian concerns in this area. The promulgation of several new statements by church bodies in different countries is anticipated during the next several months. More and more rapidly the neglects of the past are being redressed with new insight and conviction.

\section{IV}

\section{Functions of the State}

Under the head of "the ethics of population control," something further needs to be said about the role of the state in this matter, As indicated at the outset, most of what needs to be said is negative in character, to indicate the limitations that should apply to action by governments. For the role of the state is distinctly secondary and subordinate to the responsibility of husband and wife, in the Evangelical view. Indeed, not many Protestant statements deal with this dimension of the question. Yet, there are enough to indicate a few clues to the general approach.

A little attention has been paid to the question of promoting a population policy through educational means, if not to the demographic implications of tax laws and social legislation. A Commission of the Church of Scotland said in I944 that ${ }^{77}$

it may be doubted whether any policy of all-around advance in social welfare can succeed unless a clear and adequate population policy has been devised and made persuasive and acceptable to the majority of the citizens by all the resources of modern mass-education.

The International Convention of the Disciples of Christ listed in $195^{8}$ as the first of three factors for the minimization of world population pressures: "population control based on education concerning the use of efficient birth control techniques."78 It is interesting that while the second statement was made against the background of concern over the population explosion, the first had as its background fears of ethnic or racial decline in Western Christendom.

\footnotetext{
${ }^{70}$ Gibbons \& Burch, Physiologic Control of Fertility: Process and Morality, 138 AM. Ecclesiasticas Rev. 246 (1958).

${ }^{77}$ Church of SCOTLand, op. cit. supta note 20 , at 128 .

${ }^{78}$ Compendium pt. I, at 3 .
} 
The main issue in regard to governmental duties in Protestant statements is the question of legislative sanction for contraceptive means regarded as necessary by the majority of Protestant couples for their exercise of responsible parenthood. As a report to the Presbyterian Church of Ireland stated in 1951: "Prohibition by a civil government of the use of contraceptives is an infringement of the rights of individuals and an unwarranted interference by the state in the affairs of the family which is the basic unit of society."79 The United Presbyterian Church, U.S.A., called in 1959 for the "repeal of laws prohibiting the availability of contraceptives and information about them for use within the marriage relationship." ${ }^{\text {"80 }}$ The American Baptist Convention similarly supported "responsible public administration of legalized methods of birth control and family planning." ${ }^{\text {11 }}$ The United Church Council for Christian Social Action made a comparable statement in $1960 .{ }^{82}$ Such statements reflect the mounting conviction that to deny couples legal access to means they accept in conscience is to deny them part of their religious freedom and is unwarranted, since legal availability does not infringe the right of others to refrain from using such means. The recent Gallup poll indicates that this principle is held by a large majority of the American people-seventy-two per cent, as against fourteen per cent opposed. ${ }^{88}$

This is less true in regard to the emergent question of foreign aid in the familyplanning field, the same Gallup poll showing fifty-four per cent of the American people in favor and twenty-nine per cent opposed. There are a few references in the most recent statements, but it is clear that more wrestling with the problems is needed for a clear position to evolve. The American Baptist Convention spoke of the need for "an increased effort to spread the knowledge and develop the social responsibility necessary to acceptable population controls." ${ }^{84}$ The Protestant Episcopal National Council urged Christian citizens "to press through their governments and through social, educational and international agencies, for measures aimed at relieving problems of population growth. ..."85 The United Church Council for Christian Social Action urged inclusion of "family limitation helps to those governments requesting them," ${ }^{, 86}$ and the Evangelical and Reformed General Council added that to deny such assistance while extending economic aid is "a self-defeating strategy." 87

${ }^{39}$ Text from the Presbyterian Church of Ireland.

${ }^{80}$ Text from the United Presbyterian Church, U.S.A.

s1 Council on Christian Soctal Progress, American Baptist Convention, Resolutions Adopted by the American Baptist Convention 13 (1959).

${ }^{82}$ Responsible Parenthood and the Population Problem, A Statement Adopted by the Council of Christian Social Action of the United Church of Christ, January 30, r960, Social Action, April r960, pp. 24,27 .

${ }^{83}$ See N.Y. Herald Tribune, Feb. 17, 1960, p. 8, col. I.

${ }^{83}$ Council on Christian Social Progress, op. cit. supra note 81, at 13.

${ }^{85}$ Text from the National Council of the Protestant Episcopal Church.

${ }^{88}$ Responsible Parenthood and the Population Problem, A Statement Adopted by the Council of Christian Social Action of the United Church of Christ, January 30, sg6o, Social Action, April 1960, pp. 24,27 .

${ }_{8 \pi}$ Text from the Evangelical and Reformed General Council. 
So far, there has been an unfortunate tendency both in Protestant and other circles to view the issue in too limited fashion, as a question of United States bilateral material aid in the family-planning field-or alternatively as a question of securing "advice" from the private agencies. In the first place, the largest sectors in the extension of family planning in countries wanting it are education and community organization, and assistance in these sectors need not directly raise the question of birth control. Further, more generous economic assistance in general can enable countries seeking to promote the regulation of fertility to allocate more of their own limited resources to the provision of material means. Again, the needed stepping-ü of research on improved methods, which presently exceeds the resources of the private agencies, need not-indeed, should not-be limited to the development of simpler and less expensive contraceptives. The development of aids to make periodic continence more reliable also has an important claim, as Bishop James A. Pike and the writer have urged. ${ }^{88}$

It is not to be expected that Protestant church bodies will deal with the technical details of a more adequate response by the developed countries to the growing desire of less-developed countries for assistance in the field of fertility regulation. What is to be expected is a more insistent assertion by Evangelical churchmen that more attention be paid to this neglected sector of international developmental assistance, in accordance with the desires, needs, and moral convictions of the peoples aided-not as a substitute for economic aid, but as an essential supplement. Foreign aid that rightly helps to spread international disease control, the major new factor in mounting population pressures, must also take into account the consequences and help to cope with them, as part of a world-wide development strategy. As the Protestant consensus becomes broader and deeper, the writer believes this will be one of its emphases.

Yet, the main focus will not be here, but rather on the doctrine of responsible parenthood and its meaning for the family in the differing societies of today. The chief task of the churches in this field is to enrich and clarify the meaning of parent:hood in terms relevant to contemporary social problems. This is a task for church leadership, but it is equally a task for church members, the husbands and wives called to the vocation of parenthood. If there is a proper place for family planning, as the Archbishop of Canterbury said recently, "then it is necessary also to say that it is a Christian duty for parents to discover conscientiously before God what in their own family life that proper place is." ${ }^{\text {. }}$

${ }^{88}$ See statement by Rt. Rev. James A. Pike, quoted in UPI dispatch of Mareh II, I960; statement of writer to Planned Parenthood Federation, Nov. I7, 1959; Fagley, What Should U.S. Do About World Population Problem?, 39 Foreign Policy Bull. 133 (1960).

"Canterbury Diocese Notes, March 1960, quoted in N.Y. Times, March 24, 1960, p. 12, col. I. 